\title{
Når tarmen slår seg vrang
}

I et fornøyelig innlegg om sine mageplager beskriver Helge Stormorken symptomer fra fordøyelseskanalen. De debuterte da han var rundt 82 år og er sjenerende nok til at det er ønskelig med mottrekk. Han reiser spørsmålet om denne lidelsen ikke har vært interessant nok til å bli gransket fordi den kun opptrer hos eldre og utrangerte eller fordi forskerne har kvidd seg for en slik jobb. Diagnosen sterkoraldiaré fortjener en erstatning, mener han.

Sterkoraldiaré (alternativt obstipasjonsdiaré) er meg bekjent knapt benyttet som diagnose i klinisk praksis. Begrepet har snarere vært brukt som beskrivelse av et fenomen med siving av løs avføring som en konsekvens av avløpshinder i tykktarmen, for eksempel pga. svulst, eller hard og knollete avføring som ledd i forstoppelse. Ved slike symptomer er koloskopi indisert.

\section{Irritabel tarm?}

Symptomene som beskrives av Stormorken, kan være forenlig med irritabel tarm-syndrom. Magesmerter/ubehag knyttet til et endret avføringsmønster med vekslende diaré og forstoppelse er klassiske og lett gjenkjennelige symptomer ved denne fascinerende, tidvis høyst plagsomme og helt ufarlige mageplagen. Irritabel tarm kan debutere i alle aldre, fra tidlig barnealder til sen voksenalder. Stormorken beskriver i tillegg symptomer som utspilt og oppblåst mage, andre luftplager som raping og promping, inkomplett tømning av avføring, eks- plosiv avføring, ubehagelig lukt og slim i avføringen. Dette er musikk i ørene til dem av oss som mener at de fleste diagnoser i medisinen fremdeles best stilles på bakgrunn av en grundig anamnese og god symptombeskrivelse. Gastroenterologer bruker stadig mer tid i «slangeparker» med avansert endoskopisk utstyr. Gastroskopi og koloskopi er helt nødvendige undersøkelser for å oppdage alvorlig sykdom som kreft, magesår og inflammatorisk tarmsykdom. Like nødvendig er det å innse at endoskopiske undersøkelser kun er egnet til å diagnostisere et mindretall av sykdommene med symptomer fra fordøyelseskanalen.

Årsaken til irritabel tarm-syndrom er fremdeles ukjent. Tilstanden bør forstås som en hjerne-tarm-lidelse der samspillet mellom biologiske og psykososiale faktorer påvirker utvikling og forløp av mageplagene. Det pågår omfattende forskning på årsaksfaktorer ved irritabel tarm. Mens vi venter på en eventuell forklaring på denne og en rekke andre gåtefulle tilstander og sykdommer, er våre pasienter prisgitt at vi leger gjør en best mulig jobb basert på eksisterende kunnskap. Inntil videre er følgende anbefalinger vektlagt $i$ internasjonale retningslinjer $(1,2)$ : Man bør kunne stille diagnosen basert på de typiske symptomene og begrense omfattende utredning til pasienter hvor det er god indikasjon. Viktige differensialdiagnoser er tykktarmskreft, inflammatorisk tarmsykdom, cøliaki og medikamentbivirkninger. Alarmsym- ptomer som blod i avføringen og vekttap krever rask somatisk utredning. Man bør kunne formidle diagnosen irritabel tarmsyndrom med trygghet og berolige pasienten med at slike mageplager er helt ufarlige, selv om de kan være høyst plagsomme. Eksplisitte spørsmål om bekymring for kreft og alvorlig sykdom kan være nyttige. Videre trenger pasienter god kunnskap om hva irritabel tarm er og hvordan de best kan leve med sine mageplager. Slik kunnskap er tilgjengelig i håndbøker (3). Det finnes effektiv behandling for flere av symptomene ved irritabel tarm. Aller viktigst er kanskje likevel det å mestre en tarm som slår seg vrang.

\section{Per Olav Vandvik}

per.vandvik@start.no

Medisinsk avdeling

Sykehuset Innlandet Gjøvik

2819 Gjøvik

\section{Oppgitte interessekonflikter: Ingen}

Litteratur

1. Longstreth GF, Thompson WG, Chey WD et al. Functional bowel disorders. Gastroenterology 2006: 130: 1480-91.

2. Spiller R, Aziz Q, Creed A et al. Guidelines on the irritable bowel syndrome: mechanisms and practical management. Gut 2007; 56: 1770-98.

3. Moriarty KJ. Forstå irritabel tarm. Oslo: Exlibris, 2007

Manuskriptet ble mottatt 25.1. 2009 og godkjent 17.2. 2009. Medisinsk redaktør Siri Lunde. 